\title{
LONG TERM DEVELOPMENT OF FOREST STAND STRUCTURE FolloWing CATASTROPHIC FIRE IN Yellowstone National PARK: Do LANDSCAPE LEgACIES PERSIST?
}

\author{
WILLIAM H. ROMME $\uparrow$ DEPARTMENT OF BIOLOGY \\ FORT LEWIS COLLEGE $\uparrow$ DURANGO $\uparrow \mathrm{CO}$ \\ DANIEL M. KASHIAN $\downarrow$ DEPARTMENTS OF ZOOLOGY \\ AND FOREST ECOLOGY \& MANAGEMENT \\ UNIVERSITY OF WISCONSIN-MADISON $\downarrow$ WI
}

\section{$\downarrow \quad$ INTRODUCTION}

The importance of large, infrequent natural disturbances, particularly as they influence postdisturbance succession, is well recognized. The conceptualization of ecological systems and landscapes as mosaics of patches generated by disturbance emphasizes successional change, which in turn is a major component of ecologists' understanding of disturbance in a landscape context. However, paradigms of succession largely evolved for small-scale dynamics. Subsequently, these paradigms do not adequately predict the spatial variability that occurs within the perimeter of large, infrequent disturbances, nor do they adequately consider the effects of heterogeneity on recovery of the system. Understanding the nature of the disturbance mosaic and the factors controlling landscape patterns are crucial for predicting ecosystem dynamics and vegetation development in disturbance-prone landscapes, and research that addresses these questions remains a priority.

Landscape heterogeneity following large, infrequent fires is represented by a patchwork of burned and unburned vegetation as well as by a mosaic of burn severities (Turner et al. 1997, Romme et al. 1998), so that the mosaic of stand structure and function produced by fire is a legacy of the disturbance itself as well as that of the pre-fire forest. In this sense, large, infrequent fires are thought to impose a persistent influence on landscape pattern. Landscape pattern has large implications for biodiversity, determines the connectivity of habitat, affects the spread of disturbances such as insect outbreaks, and may influence the initiation and spread of small, frequent surface fires by affecting the spatial distribution of fuels. Similarly, spatial heterogeneity in stand structure that exists across a landscape may influence the propagation of crown fires (Van Wagner 1977, Turner and Romme 1994). Clearly, understanding the changes that occur in landscape pattern provides the key to understanding the dynamics of many ecological processes.

Our study examines the natural changes that occur in landscape pattern with succession in Yellowstone National Park (YNP) between large, infrequent wildfires. The 1988 fires in YNP created a mosaic of burn severities that produced tremendous variation in density of lodgepole pine (Pinus contorta var. latifolia) seedlings across the landscape (Turner et al. 1994). Because the Yellowstone mosaic of post-fire seedling densities varies from high-density 
stands $(>50,000$ trees/ha), which will inevitably be subject to self-thinning, to low-density stands $(<500$ stems/ha) which have the potential to be colonized by seed sources from outside the post-fire stand (Turner et al. 1997), tree density in initially dissimilar stands may potentially converge with time, thereby affecting landscape pattern. Although investigators have speculated that the post-fire mosaic of initial successional pathways will persist until the next large, infrequent fire (Anderson and Romme 1991, Ellis et al. 1994, Wallin et al. 1994, Turner et al. 1997), little data exists to quantify the degree of persistence of this landscape legacy.

In the summer of 2000 , we initiated a study of the long-term development of the individual patches (forest stands) that constitute the mosaic in order to understand the degree to which a major disturbance will determine landscape pattern over the long term. The data collected during that period continues to be analyzed and incorporated into modeling efforts and will be supplemented with additional field data collected during the summer of 2001. Our study addresses two major questions in the context of a disturbance-driven forest landscape: i) Do the initial differences in stand density that exist immediately after stand-replacing fires converge with stand development, and what are the rates and mechanisms of this convergence?; and ii) Based upon empirical data of stand dynamics for YNP, how is the spatial arrangement of stands of differing structural characteristics likely to change before the next large, infrequent disturbance?

\section{$\uparrow \quad$ STUDY AREA}

Research sites for this study are located on the high, forested, subalpine plateaus of Yellowstone National Park in northwestern Wyoming. Approximately $80 \%$ of the plateaus are dominated by lodgepole pine, although subalpine fir (Abies lasiocarpa) and Englemann spruce (Picea engelmannii) are co-dominants on fertile sites. The 1988 YNP fires affected about $45 \%$ of this area, or about 250,000 ha. The climate is cool with moist springs and dry summers. Moisture increases with elevation, which ranges in the park from approximately 6,400 to 10,000 feet, although most of the subalpine plateaus range from about 7,200 to 8,700 feet. Nearly two-thirds of the park includes dry, infertile soils derived from rhyolite, and the remainder includes more mesic and fertile andesites and lake-bottom substrates. Variation in site productivity is generally very low within each of these soil types. Thus far, stands were sampled on flat topography on infertile substrates (rhyolites) at elevations between 7,200 and 8,500 feet. Stands located on fertile substrates (andesites) will be sampled in the summer of 2001.

As is the case in many of the forested ecosystems of the Rocky Mountains, fire has played a dominant role in influencing the flora, fauna, ecological processes, and landscape patterns of YNP. Although the extent and severity of the 1988 YNP fires were the largest since the early 1700 s, these fires probably represent a major natural disturbance event that occurs at intervals of 100 to 300 years in this landscape (Romme and Despain 1989). During the interval between these large, infrequent fires, small fires (usually 1-3000 ha) frequently burn the YNP landscape (Turner et al. 1994). There were 235 of such fires that burned in the park between 1972 and 1987 following a period of fire suppression that occurred since the early $20^{\text {th }}$ century. As a result of this fire regime, YNP contains a mosaic of young seedling stands created by the 1988 fires as well as a mosaic of stand ages ranging from 25 to 450 years old.

\section{$\uparrow \quad$ METHODS}

Field methods and sampling designs used in the 2000 field season were tested as part of a pilot study conducted in YNP during the summer of 1999. Stands at least 5-ha in size were sampled using one $10 \times 50-\mathrm{m}$ plot per stand. Plots containing fewer than 100 live lodgepole pines were extended in length until they contained a suitable number of trees for sampling. Four discrete stand age classes $(50-100$ years, $125-175$ years, $200-250$ years, and $300-350$ years) were sampled using a stratified random sampling design, including a minimum of eight stands representing the range of stand density (as determined from aerial photographs and field reconnaissance) in each age class. A total of 33 stands were sampled during the summer of 2000 . The location and average elevation of each stand was determined using a Global Positioning System (GPS) at the center point of the plot.

For all stands, the diameter at breast height $(\mathrm{DBH})$ and $\mathrm{X}-\mathrm{Y}$ coordinates of all live and dead trees $>2.5 \mathrm{~cm}$ was determined within the $10 \times 50-\mathrm{m}$ grid. An increment core was extracted from each tree $30 \mathrm{~cm}$ from ground level for use in age determination and the construction of stand age structures. Approximately 8,300 increment cores were collected during the summer of 2000 and are currently being processed and analyzed. An estimate of the number of years 
required to reach core height was made by constructing regression equations with seeding height and age. Stand density was compared between age classes and its variability examined within age classes. Variation in age structure will be examined by comparing age class distributions between stands. Conditions of past stand density and rates of stand development will be interpreted using analyses of annual ring width patterns. Annual ring widths of live and dead boles are currently being measured using the software package WinDENDRO, and a master chronology and cross dating will be determined using the COFECHA cross-dating program (Holmes 1983).

Modeling techniques that integrate our field data are being used to address our second study objective. To simulate landscape change through time, a heuristic, spatially-explicit, cell-based model was constructed within a GIS environment, where a series of mapped data layers, each containing values of a separate parameter, are used to estimate the characteristics of stand structure in each cell. Rules for the model were constructed using parameters estimated from empirical data (threshold density for self-thinning or colonization, self-thinning trajectories, and the rate of increasing stand density) or from published values (effective seed dispersal distance, age of sexual maturity, and probability of establishment). Variables include distance to seedproducing green edge, serotiny condition, and postfire seedling density. Landscape pattern analyses were performed using the program FRAGSTATS. Analyses were completed at ages that correspond to the midpoint of the age classes used in field studies ( 75 years, 150 years, 225 years, and 300 years).

\section{$\downarrow \quad$ ResUltS AND DisCUSSION}

If stand density is variable across the landscape for a particular stand age, then relative differences in initial post-fire stand density were likely maintained as the stands matured and developed. Stands having persistent relative densities may also be expected to have similar age class distributions, reflecting episodic establishment immediately after fire. In contrast, low variability of density at a particular stand age and dissimilar age class distributions would provide evidence for convergence of stand density, since different stands would have attained similar densities through different mechanisms (self-thinning vs. colonization).

We hypothesized that similar structures in lodgepole pine stands may result from stands that were initially dissimilar in structure (i.e., convergence). Our initial analyses of field data suggest that although great variation in initial stand density exists following the 1988 fires, consequent variation in stand development likely reduces initial relative differences in stand density and promotes convergence toward a common density across the landscape. Variation in stand density within an age class appears to decrease with stand age $(p=0.003)$, likely due to mechanisms such as self-thinning in initially dense stands and, to a lesser extent, continuous seedling establishment in initially sparse stands. Evidence for convergence towards a common density across the landscape is further supported by the similarity of density and structure in old-growth (>300 years) lodgepole pine stands in YNP. Ongoing analysis of age structures and the spatial patterns of tree age within stands of similar structure are likely to reveal much about the development and convergence of lodgepole pine stand structure.

Self-thinning appears to occur in stands with density greater than $1000 \mathrm{stems} / \mathrm{ha}$ and occurs at a rate strongly linked to the initial density of post-fire stands. Initially dense stands will likely begin to experience density-dependant mortality at an earlier age and at a quicker rate than sparser stands. Based upon field observations, we observed no self-thinning even in very dense stands ( $>80,000 \mathrm{stems} / \mathrm{ha})$ that originated following the 1988 fires, suggesting that self-thinning is initiated no sooner than 12-15 years. Notably, one mature stand (stand age $=100$ years) with high density $(10,640$ stems/ha) exhibited no sign of self-thinning, suggesting that rates of stand convergence may initially be very slow.

Because seedling regeneration at densities $<1000$ stems/ha are relatively uncommon following fire in YNP (as evidenced by the relative rarity of sparse stands following the 1988 YNP fires), stands characterized by self-thinning are much more common than those characterized by continuous seedling establishment or colonization. The specific conditions required (close proximity to unburned stands with a low percent serotiny) and narrow window available (likely the first 50-75 years following fire) for colonization to occur may also contribute to the relative infrequency of this type of stand development across the YNP landscape. Based on these specific conditions, the density of isolated, sparse or extremely sparse stands may persist until the next large, infrequent fire.

Regarding our second study question, our initial simulation studies suggest that development of stands though self-thinning and changes in the 
landscape pattern that is created following large, infrequent disturbances. We hypothesized that convergence in stand density would lead to a decrease in landscape heterogeneity with time since disturbance. Landscape change occurs mainly as a decrease in the variation of stand density and subsequent increase in dominance of those patch types representing low deviation from median density. A decrease in the number of patches and an increase in mean patch size and edge density with time suggests the coalescence of dissimilar patches with age. We also noted an increase in evenness across the landscape, suggesting convergence towards a few common patch types; however, contagion decreased with time, suggesting that these patches are well interspersed. The landscape therefore becomes less heterogeneous in terms of patch diversity, but not necessarily in terms of "patchiness" or contagion. In this sense, landscape legacies following large fires generally do not persist. Further simulation studies supported by additional field data, together with repetition of our simulations using neutral modeling techniques to create variable spatial configurations of patch types, will provide further information about landscape pattern change that occurs as a result of stand development following large fires.

\section{$\uparrow \quad$ CONCLUSIONS}

Dynamics of post-fire landscape pattern depend on magnitudes and rates of change in stand structure, the relative proportions of stand density across the landscape, and likely the initial spatial arrangement of patches produced by the disturbance. Since stand development alters the density and structure of stands until they are replaced by the next fire, the spatial pattern within the perimeter of a large fire may change greatly with time, thus reducing the importance of landscape legacies with time since disturbance. Landscape pattern is also influenced by other factors not yet included in our simulation model, such as small, frequent fires that occur during the 350-year "fire-free" interval and the drastic changes that occur in stand structure due to mountain pine beetle infestations. The field data collected thus far has proven useful in understanding the ecological relationships that occur with stand development following fire in YNP and in initiating a simulation model to describe them.

\section{LITERATURE Cited}

Anderson, J.E., and W.H. Romme. 1991. Initial floristics in lodgepole pine (Pinus contorta) forests following the 1988 Yellowstone fires. International Journal of Wildland Fire 1: 119-124.

Ellis, M., C.D. von Dohlen, J.E. Anderson, and W.H. Romme. 1994. Some important factors affecting density of lodgepole pine seedlings following the 1988 Yellowstone fires. In: Despain, D. (ed.). Plants and their environments: proceedings of the first biennial scientific conference on the Greater Yellowstone Ecosystem. Technical report NPS/NRYE/NRTR-93/XX. US Department of the Interior, National Park Service, Natural resources Publication Office, Denver, Colorado, U.S.A. Pp. 139-150.

Holmes, R.L. 1983. Computer-assisted quality control in tree-ring dating and measuring. Tree Ring Bulletin 43: 69-78.

Romme, W.H., and D.G. Despain. 1989. Historical perspective on the Yellowstone fires of 1988. BioScience 39: 695-699.

Romme, W.H., E.H. Everham, E.H., L.E. Frelich, M.A. Moritz, and R.E. Sparks. 1998. Are large, frequent disturbances qualitatively different from small, frequent disturbances? Ecosystems 1: 524-534.

Turner, M.G., and W.H. Romme. 1994. Landscape dynamics in crown fire ecosystems. Landscape Ecology 9: 59-77.

Turner, M.G., W.H. Romme, R.H. Gardner, and W.W. Hargrove. 1997. Effects of fire size and pattern on early succession National Park. Ecological Monographs 67: 411-433.

Turner, M.G., W.W. Hargrove, R.H. Gardner, and W.H. Romme. 1994. Effects of fire on landscape heterogeneity in Yellowstone National Park, Wyoming. Journal of Vegetation Science 5: 731-742.

Van Wagner, C.E. 1977. Conditions for the start and spread of crown fire. Canadian Journal of Forest Research 7: 23-34. 
Wallin, D.O., F.J. Swanson, and B. Marks. 1994.

Landscape pattern response to changes in pattern generation rules: land-use legacies in forestry. Ecological Monographs 4: 569580 . 